\title{
LONG-TERM USE EFFECT OF ORGANIC, INORGANIC FERTILIZERS AND CROP ROTATION THROUGH NINETEEN YEARS ON SOME SOIL PROPERTIES IN PERMANENT EXPERIMENT AT BAHTIM.
}

\section{SOIL CHEMICAL PROPERTIES.}

EI-Shafie, A. I. E.; H. M. Khalil and U. S. El-Bialy

Soils, Water and Environ. Res. Inst., Agric. Res. Center (ARC), Giza, Egypt

\begin{abstract}
Representative disturbed soil samples of tow successive layers $(0-30$ and $30-60 \mathrm{~cm}$ ) were collected from the permanent experimental plots at Bahtim to study the prolonged effect of permanent fertilization under two crop rotations namely, one and three years rotation on some soil chemical properties, i.e., electrical conductivity, soil reaction, soil organic matter content, total soluble ions and nutritional status (available N, P and $\mathrm{K}$ ).

The obtained results indicated that the plots of 3-year rotation recorded significantly higher values of $\mathrm{EC}, \mathrm{pH}$ and $\mathrm{OM}$ content. Sodium ion was the dominant cation in soil followed by $\mathrm{Mg}^{++}, \mathrm{Ca}^{++}$and $\mathrm{K}^{+}$, respectively, while $\mathrm{SO}_{4}^{--}$was the dominant anion followed by $\mathrm{Cl}^{-}$and $\mathrm{HCO}_{3}{ }^{-}$. Also, all soluble cations except $\mathrm{K}^{+}$, and anions as well as available $\mathrm{N}$ and $\mathrm{P}$ were relatively higher under the three-years rotation than the one-year rotation. The adverse trend was found for soluble and available K. Organic manuring resulted in significantly higher values of EC and appreciable values of OM content than the other mineral fertilizers or unfertilized one while the adverse trend was true for $\mathrm{pH}$. Also, soluble cations and anions were relatively higher due to applying organic manuring than the other fertilizers except for NPK fertilizer, which gave the same soluble anions. Farmyard manuring improved nutritional status in the soil compared with the other mineral fertilizers, where available $\mathrm{N}, \mathrm{P}$ and $\mathrm{K}$ were higher due to applying organic manuring. The soil surface layer contained significantly higher $\mathrm{OM}$ as well as available $\mathrm{N}, \mathrm{P}$ and $\mathrm{K}$ than the subsurface one, while the adverse trend was found for soluble cations, also, no clear trend was noticed for $\mathrm{pH}$ and soluble anions with soil profile depth.

No clear variation was occurred in the studied soil chemical properties such as available nutrients ( $\mathrm{N}, \mathrm{P}$ and $\mathrm{K}$ ), soluble $\mathrm{Ca}^{++}$and $\mathrm{Mg}^{++}$, soluble anions and soil organic matter content with a relative increase of such property as a result of crop rotation and long-term fertilization throughout the last nineteen years. On the contrary, an adverse trend of $\mathrm{EC}$ and soluble $\mathrm{Na}^{+}$and $\mathrm{K}^{+}$was found due to fertilization and crop rotation while $\mathrm{pH}$ value took different trends due to crop rotation only. Also, the dominant soluble ions in 2007 differed from those in 1989 where $\mathrm{Na}^{+}$and $\mathrm{So}_{4}{ }^{--}$were the dominant ions in 2007.
\end{abstract}

\section{INTRODUCTION}

It is well known that an improving soil chemical property is one of the most keys to soil fertility. Many investigators have studied long-term fertilization as an organic and inorganic and/or crop rotation as well as profile depth on soil chemical properties. It is worthwhile to be discussed, herein such effect at Bahtim permanent experiments throughout the last nineteen 
years. Heggi (1976) found that soluble calcium and sodium ions increased with depth for the plots treated with mineral fertilizers, while they decreased with depth by applying organic manure. Abdel-Naim et al. (1981) mentioned that, in Bahtim permanent experiment, the plots received chemical fertilizers had significantly higher E.C. values than those of farmyard manure or untreated one. They added that all potassium forms were relatively low in the plots of 3-years rotation comparing with those of the 1-year one; also, such forms were increased by the application of farmyard manure. Hipp and Simpson (1982) pointed out that no effect of fertilization treatments could be realized on soil pH values. Steinbrenner and Smukalski (1984) found that soil organic matter was significantly affected by crop rotation, where the highest value of such property was realized in the plots of 3-years rotation compared to that of 1-year one. They added that crop rotation resulted in a slightly increase in available soil phosphorus. Also, the values of available nitrogen are higher in plots of 3-years rotation than those of 1-year rotation. Benbi et al. (1991) showed that the application of $\mathrm{N}$ fertilizer without $\mathrm{P}$ and $\mathrm{K}$ or in combination with only $\mathrm{P}$ resulted in higher $\mathrm{NO}_{3}-\mathrm{N}$ concentration in the soil profile than the application of $\mathrm{N}$ with $\mathrm{P}$ and $\mathrm{K}$. They added that the annual application of 10 tons farmyard manure (FYM) \ha. along with NPK resulted in a relatively lower $\mathrm{NO}_{3}-\mathrm{N}$ content in the subsoil. Glendining et al. (1996) indicated that the long term application annually of 48, 96 and $144 \mathrm{Kg} \mathrm{N}$ ha., in the Broadbalk Wheat Experiment at Rothamsted (UK) has increased total soil $\mathrm{N}$ content, relative to the plots never receiving fertilizer $\mathrm{N}$, due to the greater return of organic $\mathrm{N}$ to the soil in roots, root exudates, stubble, ,...etc. They added that the long-term fertilizer treatments appeared to have no effect on carbon content but have increased the specific mineralization rate of the biomass. Also, they concluded that after applying $144 \mathrm{Kg}$ NIha. for 144 years, up to half of the $\mathrm{N}$ mineralized each year was originally derived from $\mathrm{N}$ fertilizer. Clark et al. (1998) concluded that manure application for 8 years resulted in higher soil organic $\mathrm{C}$, soluble $\mathrm{P}$, exchangeable $\mathrm{K}$, soluble $\mathrm{Ca}$ and $\mathrm{Mg}$ as well as $\mathrm{pH}$. They added that crop rotation had a significant effect on organic C levels. Freixo et al. (2002) noted that crop cultivation led to a decrease in soil organic matter content, which was higher for conventional tillage soils ( disc plough followed by light disc Narrow wings) and such decrease was approx. $60 \%$ in $\mathrm{C}$ and $\mathrm{N}$ contents than no tillage, which was $43 \%$ at $0.5 \mathrm{~cm}$. Vigil et al. (2005) stated that an increase in soil organic matter at the soil surface, a decrease in soil $\mathrm{pH}$ has all been associated with the change from conventional winter wheat summer fallow to the intensive no-till rotations.

The aim of the present study is to study the probable changes of some chemical properties of the Bahtim permanent experimental plots, which have taken place through soil profile as a result of crop rotation, organic and inorganic fertilization throughout the last nineteen years. 


\section{MATERIALS AND MEATHODS}

To achieve the aim of this study, soil samples were collected from the permanent fertilization experiment at Bahtim. The presentation of the used materials and methodology of Bahtim permanent experimental plots can be shown under the following subheadings:

1. Crop rotation: 1 -years rotation $=$ cotton yearly, 2 - year rotation $=$ cotton followed by wheat then corn and 3- year rotation = cotton followed by clover then corn followed by wheat then corn.

2. Fertilization treatments: $0=$ without fertilizers (control), $\mathrm{N}$ with a rate of 15 $\mathrm{kg} \mathrm{N}$ lfad. for cotton and wheat and $22.5 \mathrm{~kg} \mathrm{~N} / \mathrm{fad}$. for corn added as ammonium nitrate $(33.5 \% \mathrm{~N}), \mathrm{NP}=\mathrm{N}$ with the same level $+\mathrm{P}$ with the level of $23.25 \mathrm{~kg} \mathrm{P}_{2} \mathrm{O}_{5} \backslash \mathrm{fed}$. in the form of calcium superphosphate $(15.5$ $\left.\% \mathrm{P}_{2} \mathrm{O}_{5}\right), \mathrm{NPK}=\mathrm{NP}+\mathrm{K}$ with $48 \mathrm{~kg} \mathrm{~K} \mathrm{~K}_{2} \mathrm{O}$ fed. as potassium sulphate $(48 \%$ $\mathrm{K}_{2} \mathrm{O}$ ), while farmyard manure (FYM) is added at a rate of 15 ton $\backslash$ fed. The rate of such fertilizers is added for each crop.

3. Soil sampling: Disturbed soil samples were collected from two successive layers namely: $0-30$ and $30-60 \mathrm{~cm}$ of the various plots of different fertilization treatments mentioned above under 1 - and 3 - year rotations.

4. Determination: soil samples were air dried, crushed and sieved through $2 \mathrm{~mm}$ sieve for chemical analysis according to Jackson (1973). Electrical conductivity $(\mathrm{EC})$ as $\mathrm{dS} / \mathrm{m}$ at $25 \mathrm{C}^{\circ}$ and soluble ions were determined in (1:5) soil water extract, while $\mathrm{pH}$ value was measured in soil paste using Beckman's $\mathrm{pH}$ meter. Organic matter percentage was determined using the modified Walkely and Black's method, Jackson (1973). Soluble nitrogen, available phosphorus and potassium were also measured according to Jackson (1973). Data obtained in 2007 were compared to those presented in 1989 (El-Shafie, 1989).

Statistical analysis was done for all properties according to Snedecor and Cochran (1980).

\section{RESULTS AND DISCUTION}

Soil chemical properties studied in this work can be discussed under the following sub-headings:-

1. Electrical conductivity (E.C.):

Data presented in Table (1) indicate that the three factors under study had a significant effect on soil EC. Soil samples taken from three-years rotation recorded significantly higher EC values than those of one-year rotation.

With respect to fertilization treatments, a highly significant increase of EC value could be seen for farmyard manure treatment compared to mineral fertilization treatments or untreated one. This result is probably due to the added farmyard manure itself, which may contain some salts in its raw material. In this connection and on the contrary, Clark et al. (1998) mentioned that the addition of animal manures for 8 years in California's Sacramento Valley did not increase salinity. 
Concerning the effect of soil profile depth, EC of the surface layer (0 - 30) was significantly lower than that of the subsurface one. The increase of EC value in deeper layer may be due to the leaching of soluble salts from the surface layer as a result of the efficient drainage system established in the Bahtim experimental plots.

It is worthy to mention that, as a combined effect, the highest value of such property was observed in the deeper layer (30-60) of plots received farmyard manure under 3-years rotation, indicating a quite similar trend to that found in case of the individual factors.

From data in Table (1) noted that the trend of electrical conductivity (EC) recorded in 2007 differed much from that in 1989 where the adverse trend of rotation and fertilization treatments occurred throughout the last nineteen years.

Table (1): Effect of crop rotation, fertilization practices and soil depth on electrical conductivity $(\mathrm{EC})$, soil reaction $(\mathrm{pH})$ and organic matter (OM) \% of the Bahtim permanent experimental plots since 1989 till 2007

\begin{tabular}{|c|c|c|c|c|c|c|c|c|c|c|}
\hline \multirow{5}{*}{$\begin{array}{l}\text { Fertilizatio } \\
\text { n } \\
\text { treatments }\end{array}$} & \multirow{2}{*}{\multicolumn{4}{|c|}{$\begin{array}{c}1989 \\
\text { Rotation }\end{array}$}} & \multirow{4}{*}{$\begin{array}{l}\text { Fertl. } \\
\text { Treat. } \\
\text { (AV.) }\end{array}$} & \multirow{2}{*}{\multicolumn{4}{|c|}{$\begin{array}{c}2007 \\
\text { Rotation }\end{array}$}} & \multirow{4}{*}{$\begin{array}{l}\text { Fertl. } \\
\text { Trea. } \\
\text { (AV.) }\end{array}$} \\
\hline & & & & & & & & & & \\
\hline & \multicolumn{2}{|c|}{ One - year } & \multicolumn{2}{|c|}{ Three - years } & & \multicolumn{2}{|c|}{ One - year } & \multicolumn{2}{|c|}{ Three - years } & \\
\hline & $0-30$ & $30-60$ & $0-30$ & $30-60$ & & $0-30$ & $30-60$ & $0-30$ & $30-60$ & \\
\hline & \multicolumn{10}{|c|}{ EC in soil water extract $1: 5(\mathrm{dS} / \mathrm{m})$ at $25 \mathrm{C}^{\circ}$} \\
\hline Unfertl. & 0.55 & 0.65 & 0.51 & 0.43 & 0.54 & 0.47 & 0.48 & 0.50 & 0.70 & 0.54 \\
\hline $\mathrm{N}$ & 0.68 & 1.00 & 0.60 & 0.47 & 0.69 & 0.44 & 0.51 & 0.52 & 0.63 & 0.53 \\
\hline NP & 0.44 & 0.82 & 0.55 & 0.76 & 0.64 & 0.46 & 0.56 & 0.62 & 0.55 & 0.55 \\
\hline NPK & 0.48 & 0.73 & 0.78 & 0.63 & 0.66 & 0.49 & 0.53 & 0.64 & 0.56 & 0.56 \\
\hline FYM & 0.76 & 0.48 & 0.65 & 0.64 & 0.63 & 0.70 & 0.78 & 0.73 & 0.90 & 0.78 \\
\hline \begin{tabular}{|l|l|l|} 
Depth & $0-30$ \\
\end{tabular} & \multicolumn{4}{|c|}{0.60} & & \multicolumn{4}{|c|}{0.56} & \\
\hline (Av) $30-60$ & \multicolumn{4}{|c|}{0.66} & & \multicolumn{4}{|c|}{0.62} & \\
\hline $\begin{array}{l}\text { Rotation } \\
(\mathrm{Av})\end{array}$ & \multicolumn{3}{|c|}{0.66} & \multicolumn{2}{|c|}{0.60} & \multicolumn{3}{|c|}{0.54} & \multicolumn{2}{|l|}{0.63} \\
\hline L.S.D at $5 \%$ & \multicolumn{2}{|c|}{${ }^{*} A=0.02$} & ${ }^{* *} B=0.04$ & \multicolumn{2}{|c|}{${ }^{* * *} \mathrm{C}=0.02$} & \multicolumn{3}{|c|}{$B=0.03$} & \multicolumn{2}{|c|}{$\mathrm{C}=0.02$} \\
\hline \multicolumn{11}{|c|}{ Soil reaction $(\mathrm{pH})$} \\
\hline Unfertl. & 8.30 & 8.15 & 8.18 & 8.50 & 8.28 & 8.20 & 8.19 & 8.41 & 8.22 & 8.26 \\
\hline $\mathrm{N}$ & 8.25 & 8.35 & 8.03 & 8.20 & 8.21 & 8.12 & 8.11 & 8.03 & 8.12 & 8.10 \\
\hline NP & 8.30 & 8.20 & 8.10 & 8.15 & 8.19 & 8.07 & $8 . .05$ & 8.26 & 8.37 & 8.19 \\
\hline NPK & 8.25 & 8.30 & 7.95 & 8.45 & 8.24 & 8.12 & 8.04 & 8.19 & 8.25 & 8.15 \\
\hline FYM & 7.73 & 8.30 & 8.03 & 8.15 & 8.05 & 8.00 & 8.01 & 8.00 & 7.99 & 8.00 \\
\hline \begin{tabular}{l|l} 
Depth $0-30$ \\
\end{tabular} & \multicolumn{4}{|c|}{8.11} & & \multicolumn{4}{|c|}{8.14} & \\
\hline (Av) $30-60$ & \multicolumn{4}{|c|}{8.28} & & & 8.1 & & & \\
\hline $\begin{array}{l}\text { Rotation } \\
(\mathrm{Av})\end{array}$ & & 8.21 & & 8.17 & & & 8.09 & & 8.18 & \\
\hline L.S.D at $5 \%$ & & $A=0.02$ & $B=0.04$ & $C=0.0$ & & & $=0.04$ & $B=0.04$ & $\mathrm{C}=\mathrm{Ns}$ & \\
\hline & & & & organic r & matter ( & OM) \% & & & & \\
\hline Unfertl. & 0.89 & 0.72 & 1.19 & 0.72 & 0.88 & 1.12 & 1.04 & 1.20 & 1.23 & 1.15 \\
\hline $\mathrm{N}$ & 0.65 & 0.55 & 0.90 & 0.78 & 0.72 & 1.61 & 1.52 & 1.66 & 1.50 & 1.57 \\
\hline NP & 0.79 & 0.61 & 0.86 & 0.78 & 0.76 & 1.40 & 1.61 & 1.90 & 1.63 & 1.64 \\
\hline NPK & 0.95 & 0.67 & 0.98 & 0.80 & 0.85 & 1.60 & 1.46 & 1.48 & 1.66 & 1.55 \\
\hline FYM & 1.74 & 0.69 & 1.55 & 1.01 & 1.25 & 2.36 & 2.28 & 2.31 & 2.41 & 2.34 \\
\hline \begin{tabular}{|l|l|} 
Depth $0-30$ \\
\end{tabular} & & & .05 & & & & 1.6 & & & \\
\hline$(\mathrm{Av}) \quad 30-60$ & & & .73 & & & & 1.6 & & & \\
\hline Rotation (Av) & & 0.82 & & 0.95 & & & 1.60 & & 1.70 & \\
\hline L.S.D at $5 \%$ & & 0.09 & $B=0.14$ & $C$ & .09 & & $=0.02$ & $3=0.04$ & $C=0.02$ & \\
\hline
\end{tabular}




\section{Soil reaction $(\mathrm{pH})$ :}

Data illustrated in Table (1) show that crop rotation and fertilization affected significantly soil reaction $(\mathrm{pH})$, while the effect of soil profile depth didn't reach the significance level on such trait. The plots of 1-year rotation recorded the lower $\mathrm{pH}$ values than those of 3 - years one. On the other hand, the plots fertilized with organic manure (FYM) had the lowest values of such property, while the highest ones were recorded for the unfertilized plots. The elucidation of the last result could be based on the higher content of organic matter in plots received FYM as buffering agent, which plays an important role on soil buffering action.

Results also revealed that the lowest $\mathrm{pH}$ value was noticed in the plots receiving farmyard manure either in one-year rotation or three-year one. This result may be due to that the most important role, herein, on such property is attributed to fertilization factor.

It could be noticed that as a general pattern, the $\mathrm{pH}$ values estimated in 2007 are nearly in similarity to those determined in 1989, however, the trend of such $\mathrm{pH}$ values was a little bit different due to the effect of crop rotation and soil depth, where the adverse trend of crop rotation effect occurred in 2007 as mentioned previously, while the effect of fertilization was the same throughout the last nineteen years.

\section{3- Soil organic matter content (OM) \%:}

Data in Table (1) revealed that all variables under study had a significant effect on the percentage of soil organic matter. Apparently, such property of 3 - years rotation was significantly higher than that of 1 - year rotation. These may be attributed to the different plant types and higher amounts of roots, which remain after harvesting, consequently produce more organic matter. This result is coinciding with that obtained by Steinbrenner and Smukalski (1984). In this connection, Benjamin and Mikha (2007) concluded that a winter wheat, corn, millet rotation had greater organic carbon than the winter wheat, fallow rotation in the cropping intensity in the Central Great Plains.

Concerning the effect of fertilization treatments, results postulated that the effect of organic manure on organic matter content \% preceded significantly the mineral fertilization treatments or unfertilized one, since it revealed an average increase amount to about 50\% more than the treatments mentioned before. This result is acceptable because of the annual application of farmyard manure, which contains a larger amount of organic matter (Clark et al., 1998). On the other hand, all mineral fertilization treatments gave a significant increase in OM content compared to the unfertilized one. The latter result may be due to the higher crop yield resulted from mineral fertilization, and consequently higher decayed roots remained after harvesting, which produced more organic matter. In this respect, Rudrappa et al. (2006) indicated that in semi-arid sub-tropical India, there was an improvement in total organic carbon in $100 \%$ NPK or $100 \%$ NP over $100 \% \mathrm{~N}$ in the surface soil.

Regarding the effect of soil profile depth, soil surface layer (the ploughed layer) showed a significant increase in soil organic matter than the subsurface one. This result agrees, to some extent, with Vigil et al. (2005). 
It is worthy to mention that the highest values of $\mathrm{OM} \%$ were realized with the application of organic manure (FYM) regardless to either crop rotation or soil depth that confirms the most important effect on such property is fertilization.

Generally, results referred that soil organic matter content during the period of 1989-2007 differed, to some extent, where they were increased throughout that period estimated to about a fold as a result of long - term fertilization. However, the trend of such property due to the studied factors in 2007 is similar to that recorded in 1989.

4- Total soluble ions:

4-1 Total soluble cations.

Data in Table (3) revealed that soluble sodium was the dominant cation in all soil samples followed by magnesium, calcium and potassium.

Table (2): Effect of crop rotation, fertilization practices and soil depth on water soluble ions $(\mathrm{meq} / \mathrm{L})$ in the Bahtim permanent experimental plots in 1989

\begin{tabular}{|c|c|c|c|c|c|c|c|c|c|c|c|c|c|c|c|}
\hline \multirow{5}{*}{$\begin{array}{l}\text { Fertil. } \\
\text { treatm } \\
\text { ents }\end{array}$} & \multirow{4}{*}{\begin{tabular}{|c|} 
Depth \\
(cm) \\
\end{tabular}} & \multicolumn{14}{|c|}{1989} \\
\hline & & \multicolumn{7}{|c|}{ One-year } & \multicolumn{7}{|c|}{ Three-years } \\
\hline & & \multicolumn{4}{|c|}{ Cations } & \multicolumn{3}{|c|}{ Anions } & \multicolumn{4}{|c|}{ Cations } & \multicolumn{3}{|c|}{ Anions } \\
\hline & & $\mathrm{Ca}^{++}$ & $\mathbf{M g}^{++}$ & $\mathrm{K}^{+}$ & $\mathrm{Na}^{+}$ & $\mathrm{HCO}_{3}$ & $\mathrm{Cl}^{-}$ & $\mathrm{SO}_{4}^{--}$ & $\mathrm{Ca}^{++}$ & $\mathbf{M g}^{++}$ & $\mathbf{K}^{+}$ & $\mathrm{Na}^{+}$ & \begin{tabular}{l|}
$\mathrm{HC}$ \\
$\mathrm{O}_{3}^{-}$
\end{tabular} & & $\mathrm{SO}_{4}$ \\
\hline & \multicolumn{15}{|c|}{ Water soluble cations and anions as $\mathrm{meq} / \mathrm{L}$ (Soil : water extract $1: 5$ ) } \\
\hline \multirow{2}{*}{ Unfertl } & $0-30$ & 4.50 & 2.96 & 0.54 & 4.54 & 5.50 & 5.51 & 1.53 & 4.92 & 3.56 & 0.43 & 2.82 & 5.80 & 2.76 & 3.17 \\
\hline & $30-60$ & 3.40 & 2.56 & 0.45 & 3.80 & 5.08 & 4.50 & 0.63 & 1.18 & 3.80 & 0.45 & 3.78 & 4.16 & 3.00 & 2.05 \\
\hline \multirow{2}{*}{$\mathbf{N}$} & $0-30$ & 3.54 & 2.64 & 0.34 & 2.57 & 3.90 & 1.85 & 3.34 & 6.12 & 2.85 & 0.31 & 2.52 & 5.51 & 1.90 & 4.39 \\
\hline & $30-60$ & 3.70 & 2.48 & 0.38 & 3.70 & 4.00 & 3.60 & 2.66 & 4.42 & 1.30 & 0.22 & 1.28 & 4.72 & 1.40 & 0.92 \\
\hline \multirow[b]{2}{*}{ NP } & $0-30$ & 2.89 & 2.08 & 0.33 & 3.50 & 3.53 & 2.76 & 2.51 & 5.14 & 3.69 & 0.45 & 3.30 & 4.96 & 2.64 & 4.98 \\
\hline & \begin{tabular}{|l|}
$30-60$ \\
\end{tabular} & 2.10 & 2.55 & \begin{tabular}{|l|}
0.38 \\
\end{tabular} & 5.60 & 5.10 & \begin{tabular}{|l|}
4.24 \\
\end{tabular} & 1.30 & 3.64 & 4.66 & 0.41 & 2.80 & 6.65 & 2.40 & 2.51 \\
\hline \multirow{2}{*}{ NPK } & $0-30$ & 4.07 & 1.86 & 0.62 & 4.68 & 3.94 & 2.79 & 4.50 & 6.01 & 2.98 & 0.58 & 3.61 & 6.34 & 2.25 & 4.60 \\
\hline & $30-60$ & 4.52 & 1.44 & 0.42 & 3.70 & 5.60 & 3.04 & 1.44 & 3.00 & 2.72 & 0.48 & 2.56 & 5.24 & 3.14 & 0.38 \\
\hline FYM & $0-30$ & 8.04 & 4.55 & 1.20 & 4.28 & 5.55 & 3.83 & 8.69 & 8.52 & 4.56 & 1.47 & 4.88 & 6.70 & 4.99 & 7.74 \\
\hline \multicolumn{2}{|c|}{$0-60$} & & \begin{tabular}{l|l}
90 & 0.
\end{tabular} & 38 & 92 & $\begin{array}{l}3.80 \\
3.9\end{array}$ & \begin{tabular}{l|l}
92 & 4 \\
\end{tabular} & .44 & 82 & 1.42 & .02 & \begin{tabular}{l|l}
62 & 7. \\
\end{tabular} & 10 & 26 & 1.52 \\
\hline
\end{tabular}

- Results obtained showed no response of soluble carbonate.

- Sulfate values were calculated by difference between total soluble cations and total soluble anions.

Table (3): Effect of crop rotation, fertilization practices and soil depth on water soluble ions (meq/L) of the Bahtim permanent experimental plots in 2007

\begin{tabular}{|c|c|c|c|c|c|c|c|}
\hline \multirow{5}{*}{$\begin{array}{l}\text { Fertilization } \\
\text { treatments }\end{array}$} & \multirow{4}{*}{\begin{tabular}{|c|} 
Depth \\
(cm) \\
\end{tabular}} & \multicolumn{6}{|c|}{2007} \\
\hline & & \multicolumn{4}{|c|}{ One-year } & \multicolumn{2}{|c|}{ Three-years } \\
\hline & & Cations & \multicolumn{3}{|c|}{ Anions } & Cations & Anions \\
\hline & & 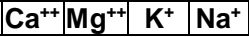 & $\mathrm{HCO}_{3}$ & $\mathrm{Cl}^{-}$ & $\mathrm{SO}_{4}^{--}$ & \begin{tabular}{|l|l|l|l}
$\mathrm{Ca}^{++}$ & $\mathrm{Mg}^{++}$ & $\mathrm{K}^{+}$ & $\mathrm{Na}^{+}$ \\
\end{tabular} & \begin{tabular}{|l|l|l|}
$\mathrm{HCO}_{3}^{-}$ & $\mathrm{Cl}^{-}$ & $\mathrm{SO}_{4}^{-}$ \\
\end{tabular} \\
\hline & \multicolumn{7}{|c|}{ Water soluble cations and anions as meq/L (Soil : water extract $1: 5$ ) } \\
\hline \multirow[b]{2}{*}{ Unfertl. } & \begin{tabular}{|l|}
$0-30$ \\
\end{tabular} & \begin{tabular}{|l|l|l|l|}
1.00 & 1.50 & 0.14 & 2.25 \\
\end{tabular} & 1.00 & 1.00 & 2.89 & \begin{tabular}{|l|l|l|l|l|}
1.00 & 1.50 & 0.01 & 3.25 \\
\end{tabular} & \begin{tabular}{l|l|l|}
1.00 & 2.00 & 2.76 \\
\end{tabular} \\
\hline & $30-60$ & \begin{tabular}{|l|l|l|l|l}
1.00 & 1.50 & 0.10 & 2.50 \\
\end{tabular} & 0.50 & 1.50 & 3.10 & \begin{tabular}{|l|l|l|l|l|}
1.00 & 2.00 & 0.26 & 4.00 \\
\end{tabular} & \begin{tabular}{|l|l|l|}
1.50 & 2.00 & 3.76 \\
\end{tabular} \\
\hline \multirow[b]{2}{*}{ N } & $0-30$ & \begin{tabular}{|l|l|l|l|}
0.50 & 1.50 & 0.12 & 2.50 \\
\end{tabular} & 1.00 & 1.25 & 2.37 & \begin{tabular}{|l|l|l|l|l|}
1.50 & 1.50 & 0.04 & 2.50 \\
\end{tabular} & \begin{tabular}{|l|l|l|}
1.00 & 1.00 & 3.54 \\
\end{tabular} \\
\hline & $30-60$ & \begin{tabular}{|l|l|l|l|}
1.00 & 2.50 & 0.11 & 3.00 \\
\end{tabular} & 1.00 & 1.50 & 3.11 & \begin{tabular}{|l|l|l|l|}
0.50 & 1.50 & 0.13 & 4.50 \\
\end{tabular} & \begin{tabular}{l|l|l|}
2.00 & 2.00 & 2.63 \\
\end{tabular} \\
\hline \multirow[b]{2}{*}{ NP } & $0-30$ & \begin{tabular}{|l|l|l|l|}
1.00 & 1.25 & 0.11 & 2.50 \\
\end{tabular} & 1.00 & 1.00 & 2.86 & \begin{tabular}{|l|l|l|l|l|}
1.00 & 2.00 & 0.12 & 3.50 \\
\end{tabular} & \begin{tabular}{|l|l|l|}
1.50 & 1.50 & 3.62 \\
\end{tabular} \\
\hline & $30-60$ & \begin{tabular}{|l|l|l|l|}
1.50 & 2.00 & 0.13 & 2.50 \\
\end{tabular} & 1.00 & 1.25 & 3.88 & \begin{tabular}{|l|l|l|l|}
1.00 & 2.50 & 0.12 & 2.25 \\
\end{tabular} & \begin{tabular}{|l|l|l|}
1.00 & 1.00 & 3.87 \\
\end{tabular} \\
\hline \multirow{2}{*}{ NPK } & $0-30$ & \begin{tabular}{|l|l|l|l|}
1.00 & 1.50 & 0.11 & 2.50 \\
\end{tabular} & 1.00 & 1.00 & 3.11 & \begin{tabular}{|l|l|l|l|l|l|}
1.50 & 2.00 & 0.13 & 4.00 \\
\end{tabular} & \begin{tabular}{l|l|l|l|}
1.50 & 2.00 & 4.13 \\
\end{tabular} \\
\hline & $30-60$ & \begin{tabular}{|l|l|l|l|}
1.58 & 2.00 & 0.11 & 2.50 \\
\end{tabular} & 1.00 & 1.25 & 3.86 & \begin{tabular}{|l|l|l|l|}
1.50 & 1.50 & 0.11 & 3.00 \\
\end{tabular} & \begin{tabular}{|l|l|l|}
1.00 & 1.50 & 3.61 \\
\end{tabular} \\
\hline \multirow{2}{*}{ FYM } & $0-30$ & \begin{tabular}{|l|l|l|l|}
1.25 & 1.40 & 0.26 & 4.25 \\
\end{tabular} & 2.00 & 2.00 & 3.16 & \begin{tabular}{|l|l|l|l|}
2.00 & 2.60 & 0.12 & 3.00 \\
\end{tabular} & \begin{tabular}{|l|l|l|}
1.00 & 1.50 & 5.22 \\
\end{tabular} \\
\hline & $30-60$ & \begin{tabular}{|l|l|l|l|l|}
1.00 & 1.50 & 0.14 & 4.25 \\
\end{tabular} & 2.00 & 2.00 & 2.89 & \begin{tabular}{|l|l|l|l|l|}
2.00 & 3.00 & 0.19 & 4.00 \\
\end{tabular} & \begin{tabular}{l|l|l|}
1.00 & 2.50 & 5.89 \\
\end{tabular} \\
\hline
\end{tabular}


With regard to the effect of crop rotation, soluble cations of soil samples taken from 3-year rotation plots were relatively higher than those of 1-year rotation, except for those of potassium, which took the adverse trend. This result is in agreement, to somewhat, with that obtained by Abdel-Naim et al. (1981).

Dealing with the effect of fertilization treatments, all soluble cations were higher in the plots treated with farmyard manure than those of mineral fertilization treatments or unfertilized one. Such result may be due to the higher organic matter content (Table, 1) in the plots fertilized with farmyard manure which resulted in more soluble cations (Clark et al., 1998). On the other hand, no clear differences in soluble $\mathrm{Mg}^{++}, \mathrm{Na}^{+}$and $\mathrm{K}^{+}$could be noticed among the plots received mineral fertilizers, however, soluble calcium was relatively higher in the plots of NP or NPK than those of N or unfertilized one. This result may be attributed to the continuous application of phosphates' fertilizer (calcium superphosphate) which contains calcium salts.

Regarding the effect of soil profile depth, in general, no clear difference in soluble cations could be noticed between the surface and subsurface layers, but it could be said that soil subsurface layer contained a little increase in soluble cations compared to surface one.

Data also scored that the highest values of soluble cations were existed in the subsurface layer of the farmyard manure plots under 3-years rotation, with exception of $\mathrm{Na}^{+}$concentration, which was the highest in the subsurface layer of $\mathrm{N}$ treatment under 3-years rotation. This result may be attributed to the effect of individual factor, mentioned above on such cations. This result stand in accordance, to somewhat, with that of Heggi (1976).

In general, it can be concluded that the most effective factor on soil soluble calcium, magnesium concentration was soil organic matter, while sodium was mainly affected by soil salinity (Table, 1 ).

To shed light on the influence of the factors under study throughout the period of 1989-2007, the results in Tables (2\&3) show that the trend of soil soluble $\mathrm{Ca}^{++}$and $\mathrm{Mg}^{++}$in 2007 is nearly similar to that found in 1989 especially the effect of fertilization, while the trend of soil soluble $\mathrm{K}^{+}$or $\mathrm{Na}^{+}$is different. The values of $\mathrm{K}^{+}$were the highest in the surface layer by using organic manuring under 1-year rotation while those recorded in 1989 were the highest in the surface layer of the plots treated with NPK fertilizer or farmyard manure. For $\mathrm{Na}^{+}$, the highest values were recorded in the subsurface layer of the plots fertilized with farmyard manure under 1-year rotation or the plots treated with $\mathrm{N}$ fertilizer under 1-year rotation while in 1989 , values of $\mathrm{Na}^{+}$were the highest in the subsurface layer of NP treatment or the surface one of FYM treatment, indicating the effect of soil salinity on such cation (Table, 1).

\subsection{Total soluble anions:}

Data in Table (2) indicated that soluble sulphate was the dominant anion in all samples. The effect of the studied factors on soluble anions is nearly parallel to that of soluble cations. The plots of 3-years rotation contained more soluble anions than those of 1-year rotation and such effect was remarkable on sulphate anion. At the same time, long-term fertilization 
of farmyard manure resulted in the highest concentrations of soluble anions in compared with the addition of mineral fertilizers or no addition, however, application of complete mineral fertilizer (NPK) existed in nearly similar sulphate anion to that of organic manureing. This may be due to the continuous application of potassium in the form of potassium sulphate and that reflected on more sulphate anion. No obvious trend could be observed due to the effect of soil depth.

It is quite interesting to mention that the influence of long-term fertilization, crop rotation and soil sampling depth on soluble anions in 2007 in comparison with 1989 took nearly a similar trend. However, the values of such soluble anions were lower in 2007 than those in 1989.

\section{5- Nutritional status:}

\section{5-1-Available nitrogen}

Results presented in Table (4) show that fertilization treatments and soil depth affected significantly available soil nitrogen but the effect of crop rotation did not reach the significance level.

Concerning the effect of fertilization treatments, the permanent addition of mineral fertilizer increased significantly available nitrogen compared to no addition of such fertilizers but these increases were significantly lower than that in the plots treated with farmyard manure. Considering soil depth, soil surface layer contained significantly higher available nitrogen content than the subsurface one. It is worthy to note that, as combined effect, the soil surface layer of the plots fertilized with farmyard manure under 3-years rotation contained the highest available nitrogen of the other treatments.

This finding could be elucidated to the fact that farmyard manure contains a quite respectable ratio of organic nitrogen, which therefore, is more effective in raising total soil nitrogen especially in the surface layer where mineralization process increases as a result of increasing biological activities, consequently more available nitrogen.

Comparing the effect of the studied factors on available soil nitrogen in 2007 and that in 1989, it could be noticed that the values of such nutrient in 2007 were slightly higher than those in 1989. The effect of longterm organic and inorganic fertilization and soil depth was nearly similar throughout such period (Table 4). However, the influence of crop rotation has been different since the crop rotation didn't significantly affect available nitrogen in 2007. Moreover, the combined effect of the factors under study has not nearly changed.

\subsection{Available phosphorus:}

Data in Table (4) indicated that 3-years rotation resulted in a slight increase in available phosphorus comparing with 1-year rotation but such increase didn't reach the significance level. Such slight decrement of available phosphorus in the plots of 1-year rotation may be due to the continuous cropping of cotton plants yearly in that rotation along more than 95 years wich resulted in the depletion of available phosphorus. On the other hand, the slight increase in available P under 3-year rotation may be due to the better soil management under such rotation which favors soil aggregation, consequently increase the availability of applied phosphorus. 
This finding agrees with that concluded by Steinbrennen and Smukalski (1984).

Table (4): Effect of crop rotation, fertilization practices and soil depth on available nitrogen, phosphorus and potassium content ( $\mathrm{mg} / 100 \mathrm{~g}$ soil) of the Bahtim permanent experimental plots since 1989 till 2007

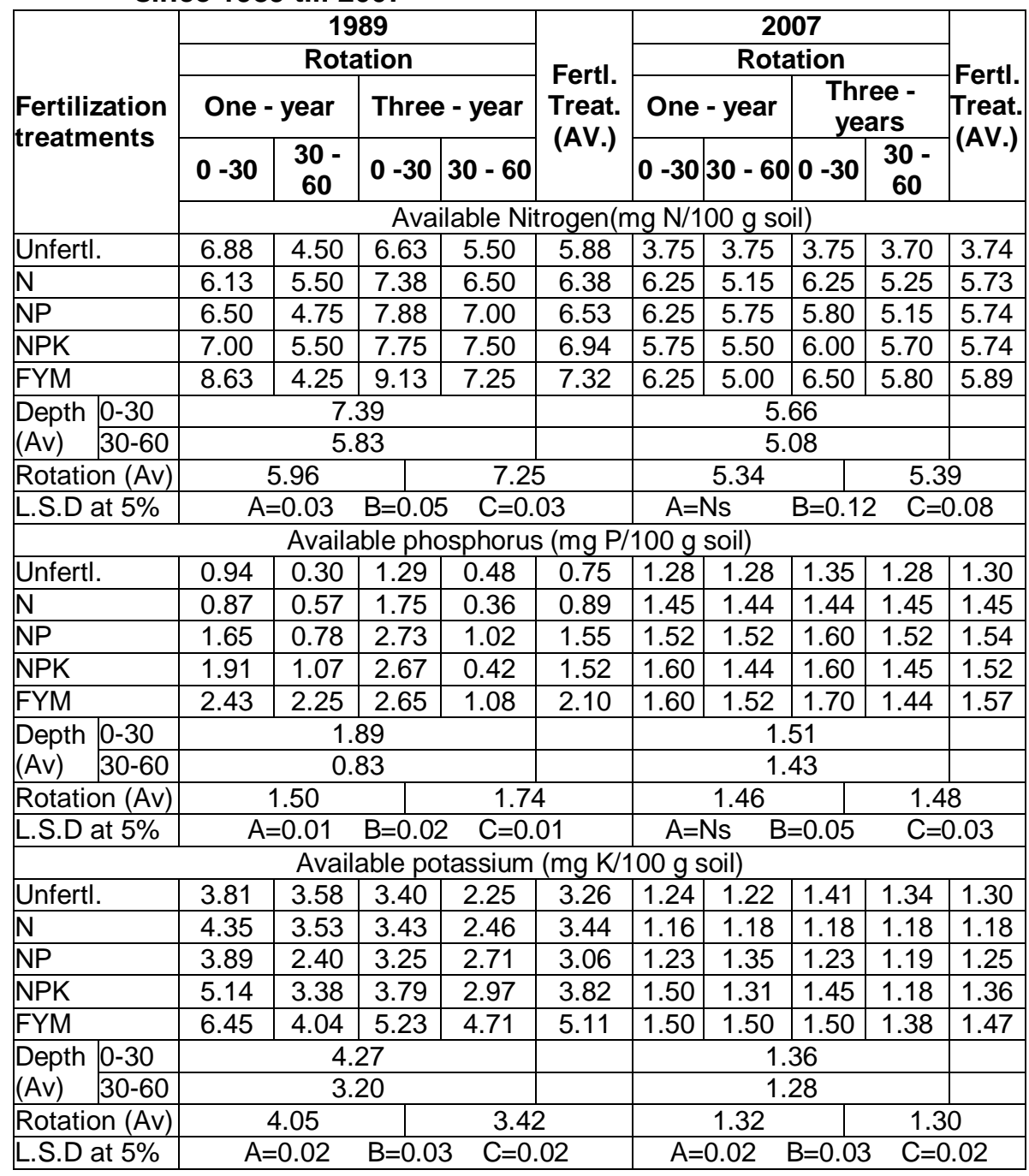

With regard to the effect of fertilization, data indicate that available soil phosphorus of the unfertilized plots followed by that received nitrogen alone were lower than those of the other mineral or organic treatments. At the same time, the highest values of such nutrient were realized in the plots treated with $\mathrm{P}$ or organic fertilizer with no significant differences among them. These 
results are quite logic indicating that the soil supplying power for available phosphorus was affected during long history of the experiment, so the effect of superphosphate applications affected significantly the available phosphorus content. Meanwhile, $\mathrm{N}$ applications and organic one which increase biological activity in soil on one side, and enhanced plant growth on the other side, reflects on transferring non available $\mathrm{P}$ to available forms. Such result is in agreement with that obtained by Clark et al. (1998).

The effect of soil depth is respectable, as the soil surface layer significantly contained higher available $\mathrm{P}$ than the subsurface one regardless different factor under study. This result may be due to, on one hand the effect of higher organic matter content in the surface layer mentioned previously and on the other hand to the slow movement of that nutrient through soil profile.

Results also revealed that soil surface layer of the plots fertilized with organic manuring or $\mathrm{P}$ fertilizer under the 3-year rotation contained the highest available soil phosphorus. Such finding is similar to that found in case of individual factors.

It is obvious that the influence of long - term fertilization and soil sampling depth during the period of 1989 to 2007 was similar while that of crop rotation was similar, to somewhat, where that effect didn't reach the significance level.

\subsection{Available potassium:}

Data in Table (4) show that all the three variables undur studies are of significant effect on available soil potassium. For rotations, available $\mathrm{K}$ of 1 year rotation was significantly higher than that of 3-year one. Similar result was obtained by Abdel-Naim et al. (1981).

Concerning fertilization treatments, the highest values of such element were significantly realized by the addition of farmyard manure. This result could be due to the effect of continuous and annual addition of farmyard manure (Clark et al., 1998). On the other hand, potassium application in the NPK treatment increased significantly the available soil potassium compared to any other mineral treatments or unfertilized one.

Regarding the effect of soil depth, available $\mathrm{K}$ in the soil surface layer was higher than that in the deeper one. This result may be interpreted to the high absorption of available $\mathrm{K}$ in the depth of $30-60 \mathrm{~cm}$ which is considered as the active soil zone of root growth.

The combined effect among the studied factors was similar to that found in case of individual ones. In other words, the highest value of available $\mathrm{K}$ was realized in the surface layer of the plots fertilized with farmyard manure or complete mineral fertilizer (NPK) and located under 1-year rotation while the lowest one was found in the subsurface layer of the plots treated with $\mathrm{N}$ fertilizer alone and located under the 3-years rotation. Such result could be elucidated to the accelerated exhaustion of the available $\mathrm{K}$ by successive crops grown under the 3-years rotation system with no adequate compensation comparing with those grows under 1-year rotation.

Comparing the influence of the studied treatment on available potassium in 2007 and that in 1989, it could be noticed that the trend of 
available $\mathrm{K}$ was similar due to all factors under study. However, available $\mathrm{K}$ values recorded in 2007 were lower than those found in 1989.

\section{REFERENCES}

Abdel-Naim, E.; N. Abou El-Ezz ; A. El- Sweedy ;S. Heggy, S. Megalla and M. R. Abdel Maksoud (1981). The effect of organic, chemical fertilization and agricultural rotation on status of potassium in Bahtim permanent experimental plots. Agric. Res. Rev., Egypt. 59:41-52.

Benbi, D. K. ; C. R. Biswas and I. S. Kalkat (1991). Nitrate distribution and accumulation in an Ustochrept soil profile in a long term fertilizer experiment. Nutrient Cycling in Agroeco systems. 28 (2): 173-177.

Benjamin, J. and M. Mikha (2007). Cropping intensity effect on organic carbon, aggregate stability and hydraulic properties of a No-till loam. Agronomy Abstract, November 5, 2007. United states Department of Agriculture (USDA), Agric. Research service. In Akron, Colorado,USA.

Clark, M. S ; W. R. Horwath ; C. Shennan and K. M. Scow (1998). Changes in soil chemical properties resulting from organic and low-input farming practices. Agron. J., 90: 662-671.

EL-Shafie, A. I. (1989). Interaction effect between rotation and fertilization on some chemical and physical properties of soil and crop yield. M. Sc. Thesis, Fac. Agric., Ain Shams Univ., Egypt.

Freixo, A. A. ; P. L. O. A. Machado; H. P. dos Santos; C.A. Silva and F. de S. Fadigas (2002). Soil organic carbon and fractions of a Ferralsol under the influence of tillage and crop rotation systems in southern Brazil. Soil and Tillage Research. 64 : 221-230.

Glendining, M. J. ; D. S. Powlsond ; P. R. Poulton ; N. I. Bradbury; D. Palazzo and Lix(1996). The effect of long-term application of inorganic nitrogen fertilizer on soil nitrogen in the Broadbalk wheat Experiment. J. Agric. Sci., 127 (3): 139-363.

Heggi, S.E.M. (1976). Some physical studies on the plots of the permanent experiment at Bahtim. M. Sc. Thesis, pp. 80 - 85. Fac. Agric, Al- Azhar Univ., Egypt.

Hipp, B.W. and B. Simpson (1982). Influence of cropping system on fertilizer response by grain sorghum and on chemical and physical properties of a virtisol. Agron. Abst., Annual Meetings : 209.

Jackson, M. L. (1973). "Soil Chemical Analysis" Prentic. Hall of India private limited - New Delhi, India.

Rudrappa, L.; T. J. Purakayastha; D. Singh and S. Bhadraray (2006). longterm manuring and fertilization effects on soil organic carbon pools in a Typic Haplustept of semi - arid sub- tropical India. Soil and Tillage Research. 88: 180-192.

Snedecor, G. W. And W. G. Cochran (1980). One way classification analysis of variance. The random effect model. Tow way classification (Eds.) in Statistical Methods, the lowa State Univ., Press, Ames, lowa, USA, 215-273. 


\section{El-Shafie, A. I. E. et al.}

Steinbrenner, K. and M. Smukalski (1984). Effect of cropping structure and crop rotation on some soil properties as demonstrated by results of International crop rotation experiments at Dewitz. Soils and Fertl., 48 : 3841.

Vigil, M. F.; D. C. Nielsen ; I. G. Benjamin ; W. B. Henry; M. M. Mikha ; F. I Calderon ; R. L. Anderson and R. Bowman (2005). Changes in soil after 14 years of No-till alternative crop rotation research. United States Department of Agriculture (USDA), Agric. Research Service. In Akron, Colorado,USA.

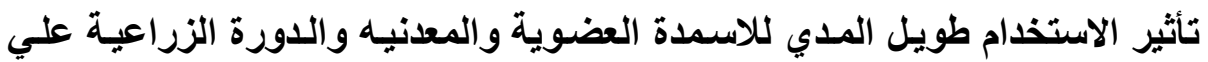

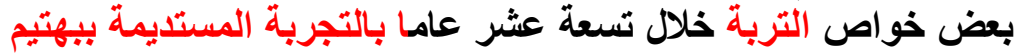

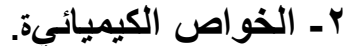

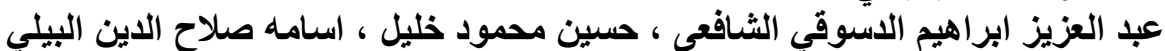

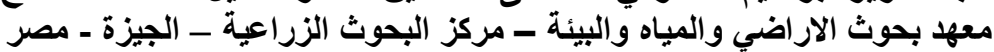

أخذت عينات تربة مثارة تمثل الطبقة السطحية وتحت السطحية لقطع تجربة التسميد المستديم ببهنيم

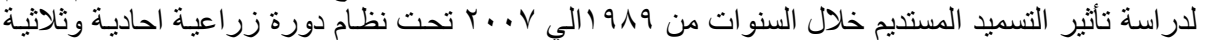

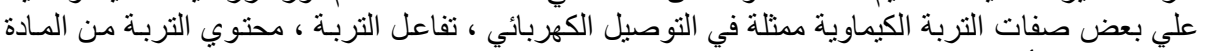

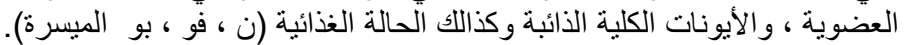

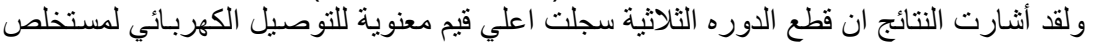

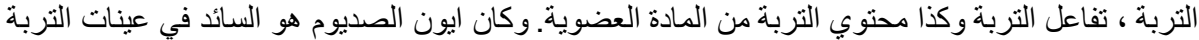

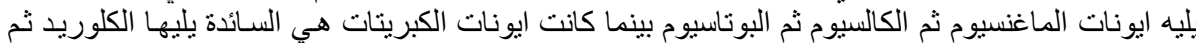

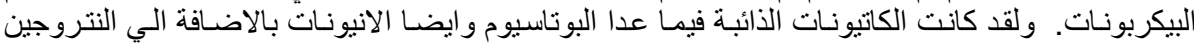

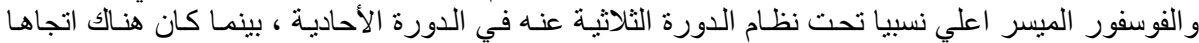

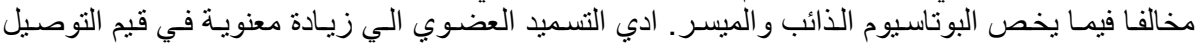

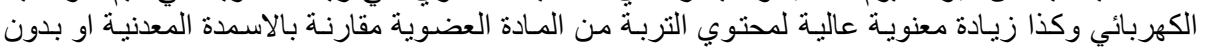

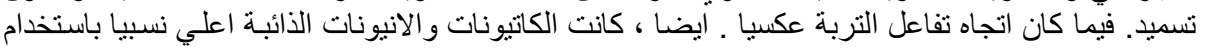

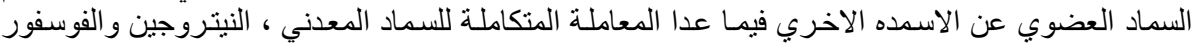

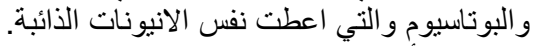

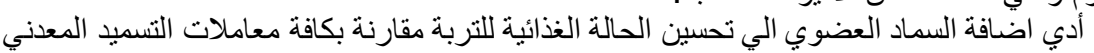

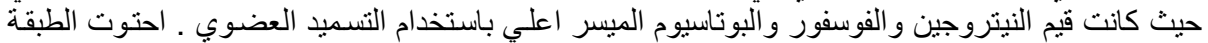

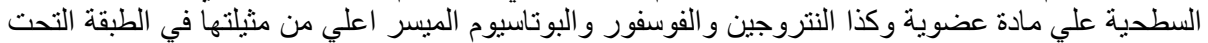

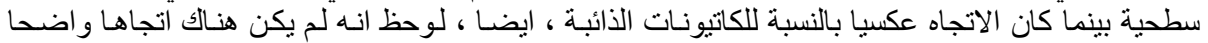

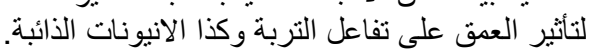

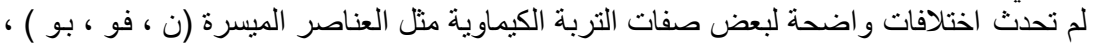

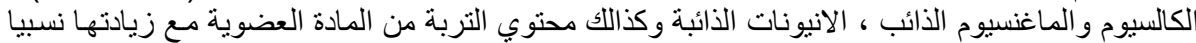

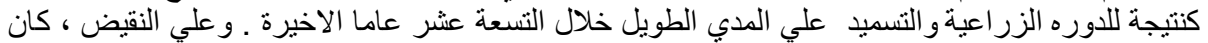

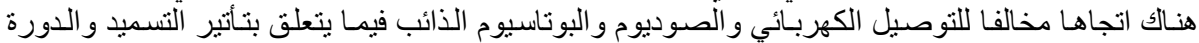

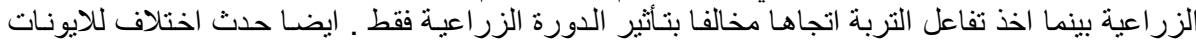

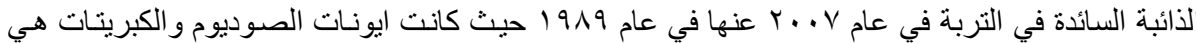

